\title{
Influence of temperature on the respiratory rate of Nile Tilapia, Oreochromis niloticus (Pisces: Cichlidae) in the laboratory
}

\author{
Ahmed S. Dan-kishiya ${ }^{1}$, John R. Solomon ${ }^{1}$, Umar A. Alhaji ${ }^{1}$ and Hadi S. Dan kishiya ${ }^{2}$ \\ 1. Department of Biological Sciences, University of Abuja, P.M.B 117, Abuja, Nigeria \\ 2. Abubakar Tatari Ali Polytechnic Bauchi, Bauchi State, Nigeria; adankishiya@yahoo.com
}

Received 19-VI-2015 • Corrected 20-VIII-2015 • Accepted 11-IX-2015

\begin{abstract}
Tilapia, Oreochromis niloticus, (Linneaus, 1758) is an important aquaculture species in Nigeria and other parts of the world. We obtained specimens $(3,5-13,00 \mathrm{~cm}$ total length; 1,7 to $49 \mathrm{~g})$ from Jabi Reservoir, Nigeria, and exposed them to $18-38^{\circ} \mathrm{C}$. The frequency of opercular beats (i.e.respiratory rate) was determined from videos. At room temperature $\left(28^{\circ} \mathrm{C}\right)$, the average frequency of opercular beats per minute for the weight groups of $1,7-3,3 ; 4,0-7,0 ; 11,0-20$ and $40-$ $49 \mathrm{~g}$ were $218,190,167$ and 119 respectively. It decreased to 153,137 , 94 and 77 beats respectively when the water temperature was lowered to $18^{\circ} \mathrm{C}$. It subsequently increased to $283,267,209$ and 136 beats respectively when water temperature was raised to $38^{\circ} \mathrm{C}(p<0,05)$.
\end{abstract}

Key words: Temperature, Respiratory rate, Oreochromis niloticus, Laboratory.
RESUMEN: La Influencia de la temperatura sobre la frecuencia respiratoria de la tilapia del Nilo, Oreochromis niloticus (Pisces: Cichlidae) en el laboratorio. La Tilapia, Oreochromis niloticus, (Linnaeus, 1758) es una especie importante de acuicultura en Nigeria y otras partes del mundo. El muestreo se realizó en el Embalse Jabi, Nigeria; se obtuvieron muestras de 3,5 a $13 \mathrm{~cm}$ de longitud (con un peso de 1,7 a $49 \mathrm{~g}$ ) y se expusieron temperaturas entre $18-38^{\circ} \mathrm{C}$. La frecuencia de los latidos operculares (frecuencia respiratoria) se determinó a partir de vídeos. A temperatura ambiente $\left(28^{\circ} \mathrm{C}\right)$, la frecuencia media de latidos operculares por minuto para los grupos según el peso de 1,7 a 3,3; 4,0 a 7,0; 11,0 a 20 y de 40 a $49 \mathrm{~g}$ fueron $218,190,167 \mathrm{y}$ 119 respectivamente. Posteriormente cuando la temperatura del agua dismuyó a $18^{\circ} \mathrm{C}$ la frecuencia de latidos disminuyó a 153, 137, 94 y 77 golpes, respectivamente. Cuando la temperatura del agua se aumento a $38^{\circ} \mathrm{C}$, los latidos aumentaron a $283,267,209$ y 136 , respectivamente $(p<0,05)$.

Palabras clave: Temperatura, frecuencia respiratoria, Oreochromis niloticus, laboratorio.
Tilapia is an important aquaculture species in Nigeria and is widely accepted by consumers. Holden and Read (1972) had showed Sarotherodon and Tilapia as the most abundant in West African water bodies. The study by Mustapha (2009) in Oyun Reservoir while in Eleiyele (Olaniran, 2003), Osinmo (Komolafe \& Arawomo, 2008) and Lower Usuma Reservoir (Dan-Kishiya, 2012) also confirmed the dominancy of tilapias in Nigerian waters but due to global warming, there is the tendency of this unique fishery resource to suffer environmental effects such as temperature.

Temperature is regarded as an environmental factor that affects the activity, behavior, feeding, growth, survival, appetite and reproduction in all fishes (Dupree \& Hunner, 1984). Temperature variations in water bodies depend largely on their geographical location (Latitude, Longitude and Altitude). In the tropics, marked variations in temperature and rainfall between the rainy and dry season affect the physico - chemical characteristics of the water. Cold water has more dissolved oxygen than warm water thus as temperature increases less oxygen is available to the biota (Akin-Oriola, 2003). Therefore, temperature has a pronounced effect on rate of chemical and biological processes in aquatic habitats. The temperature of tropical water bodies has been documented. This includes the work of Nirmal - Kumar et al. (2009) who reported a temperature variation of between $23,5^{\circ} \mathrm{C}$ to $33,5^{\circ} \mathrm{C}$ in estuarine system in Tapi, West Coast, India. The average temperature range of 28,5 to $35,4^{\circ} \mathrm{C}$ was reported (Nayak, Behera \& Das, 2012) in Chilika Lagoon, East Coast, 
India while in Nigeria; temperature range of $26,13^{\circ} \mathrm{C}$ to $31,00^{\circ} \mathrm{C}$ was recorded in lower Usuma Reservoir in Bwari, Abuja (Dan-Kishiya \& Chiaha, 2012). The present research aimed at studying the influence of temperature on the respiratory rate which is also called opercular beats of $O$. niloticus under laboratory condition.

\section{MATERIALS AND METHODS}

Sample Collection: Thirty-four (34) healthy sub-adult tilapia fish with sizes that range between 3,5 to $13,00 \mathrm{~cm}$ were collected from the fishermen catches who uses cast net, gillnet and Malian trap of various mesh sizes in Jabi Reservoir. The fishes were transported to the Biology Laboratory of the Department of Biological Sciences, University of Abuja in a 20 liters plastic bowl that is half full with water.

Laboratory Analysis: In the laboratory, the fish were allowed to acclimatize in a 50 liters plastic bowl supplied with aerators and fed regularly with commercial fish pellets. The bowl was cleaned periodically for any unused food to avoid infection. After acclimatization, the fishes were divided into five groups of six fishes each. The first two groups were exposed below room temperature $\left(18^{\circ} \mathrm{C}\right.$ and $\left.23^{\circ} \mathrm{C}\right)$ and the third group was maintained at room temperature $\left(28^{\circ} \mathrm{C}\right)$ while the fourth and fifth group was maintained above room temperature $\left(33^{\circ} \mathrm{C}\right.$ and $38^{\circ} \mathrm{C}$ ). The total length, standard length and weight of fish were measured according to a method adopted from Tarkan, Gaygusuz, Gursoy, Ozulug, Acıpınar, Bilge \& Filiz, 2006.

Respiratory rate / Determination of Number of Opercular Movement: The respiratory rate which is also the opercular beat was observed for a minute for each fish in a group by placing a single fish from each group into $1000 \mathrm{ml}$ bottom flask filled with water and placed on a tripod stand with a thermometer mounted on each flask while a digital video camera (Canon Power shot P780) positioned underneath and focused on the flask to a satisfactory zoom was programmed to record a $60 \mathrm{sec}-$ ond video of opercular movement of each fish (Pulgar, Bozinovic \& Ojeda, 2005). All recorded video were later transferred onto computer software (Windows ${ }^{\circ}$ Movie Maker ) and each analyzed at a low frame speed to determine the number of opercular movements at various temperature.

\section{RESULTS}

In the present study, the opercular beats increased with the increasing temperature and reduced with increase in both length and weight (Table 1). From the table, the fish belonging to category of $3,5-5,0 \mathrm{~cm}$ standard length had their number of opercular beats increase consistently with increase in temperature, averaging $153 \pm 9,6$ beats at a low temperature of $18^{\circ} \mathrm{C}$ and $283 \pm 11,0$ beats at the higher temperature of $38^{\circ} \mathrm{C}$. However, control $\left(28^{\circ} \mathrm{C}\right)$ was seen to maintain an average of $218 \pm 11,6$ beats per minute. As weight categories increased down the table however, the number of beats per minute showed decline with the least value recorded in the largest fish category making $77 \pm 13,1$ beats per minute at the lowest temperature $\left(18^{\circ} \mathrm{C}\right)$, then started increasing with increased in temperature to $136 \pm 19,5$ beats at the highest temperature $\left(38^{\circ} \mathrm{C}\right)$.

\section{DISCUSSION}

In present study, the frequency of opercular beats was generally proportional to function of the water temperature and inversely related to the body weight of the fish. This is in conformity with the finding of Gillooly et al. (2001) on effect of size and temperature on metabolic rate of fish. Therefore, opercular activity, which is probably a measure of oxygen consumption and metabolism of fish, were weight and thermal stress dependent

TABLE 1

Summary of Frequency of Opercular Beats (per min) for Different Categories of Tilapia Fish at Different Temperatures

\begin{tabular}{cccccccc} 
Size & \multicolumn{5}{c}{ Number of Opercular Movement } \\
Standard Length $(\mathrm{cm})$ & Weight $(\mathrm{g})$ & $18^{\circ} \mathrm{C}$ & $23^{\circ} \mathrm{C}$ & $28^{\circ} \mathrm{C}$ & $33^{\circ} \mathrm{C}$ & $38^{\circ} \mathrm{C}$ & Range \\
\hline $3,5-5,0$ & $1,7-3,3$ & $153 \pm 9,6$ & $190 \pm 9,9$ & $218 \pm 11,6$ & $246 \pm 7,0$ & $283 \pm 11,0$ & $153-283$ \\
$5,1-6,0$ & $4,0-7,0$ & $137 \pm 7,7$ & $177 \pm 7,1$ & $190 \pm 3,7$ & $236 \pm 5,9$ & $267 \pm 4,2$ & $137-267$ \\
$7,0-11,0$ & $11,0-20$ & $94 \pm 4,4$ & $118 \pm 16.3$ & $167 \pm 10,0$ & $185 \pm 5,2$ & $209 \pm 4,0$ & $94-209$ \\
$11,1-13,0$ & $40,0-49$ & $77 \pm 13,1$ & $104 \pm 5,5$ & $119 \pm 6,0$ & $127 \pm 9,7$ & $136 \pm 19,5$ & $77-136$ \\
\hline
\end{tabular}


(Tantarpale, Rathod \& Kapil, 2012). Temperature is one of the most fundamental environmental stressors, altering almost all biological processes through its actions on basic chemical reactions supporting physiological processes (Murugaian, Ramamurthy \& Karmegam, 2008).

A moderate number of opercular beats was observed in the control. However, the number of opercular beats increases with rise in temperature. The relatively moderate number of beats observed at room temperature $\left(28^{\circ} \mathrm{C}\right)$ was an indication that respiratory and metabolic rate were mild (Tantarpale et al., 2012). Therefore, as the temperatures changed, there was accompanying increase or decrease in the metabolic rate, with corresponding change in the demand for oxygen by the body, hence, the observed opercular frequencies (Weiss, 1970; Bartelme, 2006; Sukhan, Chowdhury \& Hannan, 2010).

Another factor that might have contributed to the higher frequency of opercular beats per minute at the higher temperatures is because the oxygen carrying capacity of water declined as the water temperature increased, which resulted in insufficient levels of dissolved oxygen in the water (Bartelme, 2006). Consequently, the reduced solubility of oxygen in water coupled with high metabolic rate required higher opercular beats frequency to meet an increased demand for oxygen by the tissues (Sukhan et al., 2010).

With respect to body weight, opercular beats of tilapia fish at any given temperature were observed to decrease with increasing body weight and standard lengths. This implies that the oxygen requirement of $O$. niloticus per unit body weight is inversely related to the body weight as supported in similar research by Sergovia, Munoz \& Flores (2012) on water flow requirement related to oxygen consumption in juvenile rockfish (Oplegnathus insignis) and also by Gillooly et al., (2001) on effect of size and temperature on metabolic rate of fish. This is probably because smaller fish were more active and therefore, active swimmers required more oxygen to generate energy needed to maintain life processes. Generally, in order to meet the increased demand for oxygen by the tissues, fish opercular activity was enhanced, but this too had a limit beyond which will be potentially lethal to the fish (Murugaian et al, 2008). In this case, destruction of respiratory and metabolic enzymes may have been the reason for the reduced frequency of opercular beats.

Oreochromis niloticus behaved differently at different temperatures. For the larger fishes, the effect of high temperature was abnormal behavior, cessation of movement, loss of equilibrium and rapid opercular movement. However, at low temperature $\left(18^{\circ} \mathrm{C}\right)$, the fish appeared to be in resting phase with less frequent opercular and fin movement. This is in conformity with the finding of Murugaian et al. (2008). Generally, the frequency of opercular beats per minute appeared to decrease with decreasing temperature.

\section{ACKNOWLEDGEMENT}

We thank the laboratory technicians, Biological Sciences, University of Abuja for their assistance.

\section{REFERENCES}

Akin-Oriola, G. A. (2003). Zooplankton Associations and Environmental Factors in Ogunpa and Ona rivers, Nigeria. Rev. Biol. Trop., 51(2), 391-398.

Bartelme, T. D. (2006). Metabolism, Energy Use and Feeding Behaviour in Fish. http://advancedaquarist.com/2006/4/ aafe ctures1.htm.

Dan-kishiya, A. S. (2012). A Survey of the Fishes of Lower Usuma Reservoir, Bwari, F.C.T. Abuja, Nigeria. Report and Opinion, 4(1), 48-51.

Dan-kishiya, A. S. and Chiaha, Q. N. (2012). Physico-chemical parameters of some selected stations in Lower Usuma Reservoir, Bwari, Nigeria. Report and Opinion, 4(2), 1-6.

Dupree, H. K. \& Hunner, J. V. (1984). Third Report to the Fish Farmers. The status of warm water fish farming and progress In: Fish Farming Research. U. S. Dept. of the Interior Fish and Wildlife Services, Washington D. C. 270.

Gillooly, J. F., Brown, J. H., West, G. B., Savage, V. M. \& Charnov, E. L. (2001) Effects of size and temperature on metabolic rate. Science, 293, 2248-2251.

Holden, M. \& Reed, W. (1972). West African Fresh Water Fish. Longman Group Limited London.

Komolafe, O. O. \& Arawomo, G. A. O. (2008). Preliminary observations on Fish Species in a newly impounded Osinmo Reservoir. Turkish Journal of Fisheries and Aquatic Sciences, 8, 289-282.

Murugaian, P., Ramamurthy \& Karmegam, N. (2008). Effect of Temperature on the Behavioural and Physiological Response of Catfish, Mystus gulio (Hamilton). Journal of Applied Sciences Research, 4(11), 1454-1457.

Mustapha, M. K. (2009). Fish Fauna of Oyun Reservoir, Offa, Nigeria. Journal of Aquatic Sciences. Available online at http://www.ajol.info/index.php/jas.

Nayak, L., Behera, D. P. \& Das, S. (2012). Molluscan Wood-Borers of Chilika Lagoon, East Coast of India and Their Control Measures. Current Research Journal Biological Science, 4(2), 186-191. 
Nirmal-Kumar, J. I., George, B., Kumar, R. N., Sajish, P. R. \& Viyol, S. (2009). Assessment of spatial and temporal fluctuations in water quality of a tropical permanent estuarine system - Tapi, West Coast India. Applied Ecology and Environmental Research, 7(3), 267-276.

Olaniran, T. S. (2003). Fishing activities and fish species diversity assessment in Eleyele Lake, Ibadan, Nigeria. African Journal of Livestock Extension, 2,72-74.

Pulgar, J. M., Bozinovic, F. \& Ojeda, F. P. (2005). Local distribution and thermal ecology of two intertidal fishes. Oecologia, $142,511-520$.

Segovia, E., Munoz, A. \& Flores, H. (2012). Water flow requirements related to oxygen consumption in juveniles of Oplegnathus insignis. Lat. Am. J. Aquat. Res., 40(3), 755-762.
Sukhan, Z. P., Chowdhury, M. T. \& Hannan, M. A. (2010). Climate change and its impact on fisheries resource in Bangladesh. Proc. of International Conference on Environmental Aspects of Bangladesh (ICEAB10), Japan.

Tantarpale, V. T., Rathod, S. H. \& Kapil, S. (2012). Temperature stress on opercula beats and respiratory rate of freshwater fish of Ghanna punctatus. International Journal of Scientific and Research Publications, 2, 2250-3153.

Tarkan, A. S., Gaygusuz, O., Gursoy, C., Ozulug, M., Acıpınar, H., Bilge, G. \& Filiz, H. (2006). Conversions of Total, Fork and Standard Length Measurements Based on 42 Marine and Freshwater Fish Species (from Turkish Waters). Turkish Journal of Fisheries and Aquatic Sciences, 6, 79-84.

Weiss, R. F. (1970). The solubility of Nitrogen, Oxygen and Argon in water and sea water," Deep Sea Res., 17,721-735. 